\title{
GENERAL PRINCIPLES OF INHERITANCE LAW IN THE ROMANIAN LAW AND THE MUSLIM LAW
}

\section{C.T. POPA}

\section{Carmen Teodora Popa}

Faculty of Law, Department of Law

University of Oradea, Oradea, Romania

*Correspondence: Carmen Teodora Popa, University of Oradea, s General Magheru st. Oradea, Romania

E-mail: bnppopacarmen@gmail.com

\begin{abstract}
This article discusses the general principles of legal regulation of inheritance of the Civil code in force and their comparison with those prevailing in Muslim law. The Muslim law of inheritance ab intestat -the only "legal one" because really the Muslim law is not recognized in "testamentary succession"- it produces awe to the one who discovers. Its technique, but mostly the principles with which they are at the base and the spirit that it animates (it might not be without regard for the sacred), constitute difficulties for lawyer largely influenced by French law. More than in any other system of law, we need to look in history, not so much due to tracking descendants, about which we know quite a bit, as well as with the purpose to avoid countermeasures meanings in terms of the spirit that animates this right.
\end{abstract}

KEY WORDS: MUSLIM LAW, PRINCIPLES OF LEGAL REGULATION OF INHERITANCE, SHARI `A, THE QURAN, GROUPS OF HEIRS

\section{PRELIMINARY CONSIDERATIONS REGARDING THE LEGAL SUCCESSION IN ROMANIAN LAW AND THE MUSLIM LAW}

The Muslim right "fiqh" not within the law, in the sense that we are accustomed to "modern", meaning of this expression, that is that it is not a right in the traditional sense.

Fiqh means all those prescriptions, which according to the will of God must lead man in his religious, moral and political life, so called "the doctrine of human duties". It is an "ideal", to all Muslims, we see tangible results that almost everywhere, just like "dismemberments" in this legal system built for centuries by scholars of Islam. Every Muslim state is based more or less on its principles, it generates its own rules and is no doubt that Fiqh has provided Muslim peoples the essence of their legal institutions in a positive way and has rules that even if there is a mixture of religion, morality and law, they do not lose this first character.

Understanding the mode of formation of the rules is essential in deciphering the doctrinal controversies, the multitude of conflicting views and at the same time the impossibility of giving free legal reasoning, paradox is only apparent and that is explained by Muslim history law and, in particular, its sources. In Muslim countries, the succession law is a sector that is appropriate to all and against whom no most legislators do not stand up front while acknowledging the necessity of submission. The explanation is related to roots closely linked to the matter of Qur'anic law.

An essential part of Muslim law, the succession law has remained in the modern laws strongly rooted in tradition: inequality between parties, men and women, the fractions 
assigned to fardh rules laid down in the Koran, the hermaphrodite, the "special cases" resolved by the immediate successors of the Prophet, the "daul" arithmetic calculation procedures of the parties that have originated in the middle ages.

Giving reasons on a traditional legislation from Tunisia, Morocco, Senegal, Algeria, Egypt, Syria, Saudi Arabia and other Islamic States have contributed in a way.

From the laws of the various Muslim States, we chose as reference point the Algerian Code for this study, which reflects a particularly classic legislation rules.

Algeria's Constitution proclaims Islam as the State religion, in which the legislator provides that in the absence of legal provisions to make reference to the provisions of the "Shari $a "$.

Shari $a$ means the combination of the general and common norms but with traditional and special provisions applying to all Muslim States in a proportion which can vary between $10 \%$ and $90 \%$, depending on the size of each State's secularity, the rest includes legal regulations of the respective country's legislature.

Shari a features:

Fiqh $=$ is the science of practical knowledge of the laws, more exactly Shari $a$ applied.

I. The Qur'an

II. Sunna

III. Ijmaa

Succession matters can be found as it follows:

1. The Qur'an: Women Surat - verses 7; 8; 11; 12; 176.

Surat al-Anfal - verse 75.

2. Sunna: Hadith

3. Ijmaa -represents the decisions agreed upon in unanimity of important people around the Prophet Muhammad.

4. Ijtihad - represents interpretation of important people around the Prophet Muhammad.

5. The Law (the secular one) regulates in detail the sequence which is specific to each Muslim state.

In conclusion, we can say that the top four sources of materials succession in the Muslim law are common to all Islamic countries while the latter secular law is specific to each state.

In the Muslim succession law, the sacred dates do not reduce the general indications. Prescriptions are not default to the principles of action, leaving considerable freedom to those in charge to apply it, but rather treated the whole thing in detail leaving no place for interpretations. Most imperatives are very clearly expressed, they give solution to practical cases and are made in such way that no other solution can intervene. Whether it's from the Quran or the Sunna, a relatively small number of rules led to a making it difficult for the lawyers who made a tremendous effort to build, based on such sources, a coherent set.

The Quran - is the revealed Word of God received by the Prophet, this being a sacred book. Its authority cannot be discussed and the solutions which it contains relate to everybody. Legal order is based in large part on it, although it is not a code, and the justices should not cite it to justify their decisions.

Sunna - has the appearance of short hadith stories containing the list of witnesses attesting to the the continuity and reliability of the testimonies, and the second part containing the tradition itself, that is, the word of the Prophet.

These hadith-s as well as the Quran underpinn the establishment of the most important principles of Muslim law and the activities of the various schools. They form the Shari'a or shar which means path, the divine law. 
Only on relatively these few such sources, a coherent system was built which keeps the fiqh and the intelligence effort of jurists to complete the Shari'a and give a form of Islamic law.

There is yet another aspect of Muslim law that must be disclosed, namely, that have developed four schools whose founders have tried different basic rules. Thus we can distinguish the following schools:

1. Hanefit school - founded by Abu Hanifa (767)

2. Malekit school - represented by Malek Ben Anas (795)

3. Shafeit school - founded by Al-Shafei (820)

4. Hanbalit school - founded by Ibn Hanbal (855)

The modern era shook the Muslim law to its foundations. This happened in the first place, through contacts with Europe, then by introducing "Western" codes or "Westerninspired" codes. In this context we question, if Muslim countries accept or refuse foreign influences.

The answer to this question will be the following: it is true that family law has always remained very resistant to foreign influences which made even more sensitive the dichotomy between the two legal systems and the need felt by Muslims to give it an even greater importance. In relation to the right to inherit, this is hardly accessible to modern legislators because of clarity of expression from the Quran and the Sunna. That's why you might say that in this area, the contemporary codes are remarkable close to the classic regulations.

The Muslim inheritance law is not only a technique of assigning parts of the inheritance. It reflects a spirit that translates the concept that a company has towards the relationships that exist among its members. It reflects the relative importance of its institutions and the idea of their significance. It is found at the crossroads of goods and families, it is a witness to the beliefs, it attests the priorities set out in a society.

Putting at stake the ties of blood, or alliance, the Muslim inheritance cannot be indifferent to the rules that dominate these links, not just because you can't understand and appreciate failing, but because certain issues that it raises, cannot be solved without their knowledge.

For this reason, it is necessary to go beyond the strict framework of the law of succession and the approach of the three recognized causes of fiqh: marriage, kinship and patronage.

The Muslim law confers legal inheritance to persons that are part of these categories but in actually inheritance is according to principles of succession for the inheritance laws.

It should be noted that no Muslim recognizes a will or a testament, therefore there will be no testamentary inheritance. In some situations, when the last wish manifested by someone that his patrimony shall be shared it can be considered as a testament to heirs on the condition that these last ones accept it. This testament may be verbal or written, it has no legal regulation and, hence, being left to the heirs the accepting of the conditions imposed by the deceased or not taking him into consideration and therefore following the regulations of legal inheritance.

In the Romanian civil law, the inheritance is legal where the transmission takes place under the inheritance law, in favor of the relatives of the deceased and the surviving spouse, in the order determined by law and in the proportions laid down by law.

The legal inheritance is in the regulation of the Romanian Civil code, "the most natural way of the transmission of the assets and liabilities of a deceased". This results from the fact that the legacy of the testamentary established by de cujus, is constrained by the law through a number of restrictions, the most important of which is the reserved portion.

The heritage institution is conceived within the context of legal inheritance -as a family legacy, and only in the case of vacant estate heritage this is collected by the State. Therefore, the law calls the close relatives of the deceased - from marriage, out of wedlock or adopted children-as well as the surviving spouse of the deceased. Thus, the regulation of the 
legal right of our heritage is founded on kinship existing between the deceased and the people remaining alive, whether it be blood or kinship.

\section{THE GENERAL PRINCIPLES OF LEGAL REGULATION OF TRANSFER ON SUCCESSION ROMANIAN CIVIL CODE}

In the matter of the General principles of inheritance law, the solution proposed by the New Civil code maintains the fundamental rules that have been outlined and which were found in the Civil code and regulation from 1864.

According to art. 963 para. 1 of the Civil code, the legal legacy comes in order and with the rules laid down, the surviving spouse and the relatives of the deceased, the descendants, and the collateral ascendants, where appropriate.

The relatives of the deceased with general legal succession are not called all together and in the same time for the inheritance, the legislator makes a specific order calling the heirs. For this purpose, two scientific-technical criteria are used: the group of heirs and the degree of kinship.

The group is made up of a cathegory of relatives (eg descendants of the deceased) who collectively exclude categories or is excluded from it, even if relatives from the excluded category are nearest in degree than those of the called category.

The kinship is a number that represents direct line births from one person to another, and on the sideline, all births from a common ancestor and down from a relative to the other relative to it.

On the basis of classes of heirs and the degree of kinship three principles of legal inheritance were developed:

- the principle of the classes of heirs

- the principle of the degree of kinship

- the principle of equality between relatives of the same class and the same degree of kinship

A. The principle of the classes of heirs

The Civil code has established four legal groups of heirs:

a) group I, the descendentans, made of children, grandchilren, great grandchildren and so on without a limit of the degree;

b) group II, a mixture of the privileged ascendants (parents of the deceased) and the collateral (brothers, sisters of the deceased up to including the $\mathrm{IV}^{\text {th }}$ degree);

c) group III, of the ordinary ascendants, (grand parents, great grandparents, and so on without a limit of this degree);

d) group IV, the ordinary collaterals (uncles, aunties of the deceased, first degree cousins and brothers and sisters of the grandparents of the deceased).

Under this principle, the relatives are called to the inheritance in the order of the classes of heirs. Hence, first called to inherit is class I of relatives of heirs, excluding heirs from any other class. In the absence of class I successors, relatives in class II of the heirs are called who will exclude from the inheritance the inferior relatives. The class of the ordinary ascendants will only happen in the absence of heirs of the first two classes, and the last class of heirs may inherit in the absence of successors from all other classes.

If after disinheritance, the relatives of the deceased from the closest class can not collect the entire inheritance, then what it remains shall be awarded to relatives qualifying for the subsequent class to inherit. For example, if all relatives of a class are disinherited legacy is gathered by relatives in subsequent class, under the condition of respecting the right as a reserve of reserved heirs. Thus, if the deceased had disinherited a whole class of descendants after assigning legal reserve for them, the inheritance is assigned to class II of heirs.

As an exception to this principle, the widow of the deceased, who is not related to him and is not part of the class of heirs, comes into the contest with any of these classes; 
therefore, he does not exclude any class of heirs, but also not removed from the inheritance of any of the classes, even the first called by the law of inheritance.

B. The principle of the degree of kinship

According to this principle, covered in art. 964 par. 3 of the Civil Code, within each class, the nearest degree relatives of deceased relatives remove relatives from farthest degree, unless the law provides otherwise.

For example, children of the deceased, the $\mathrm{I}^{\text {st }}$ degree of kinship, removes the grandchildren, who are second degree relatives to the deceased; brothers and sisters of the deceased, second degree relatives remove the grandchildren of brothers; uncles and aunts of the deceased, relatives of third degree, remove cousins of the deceased, who are fourth degree relatives with the deceased.

The law has two exceptions from this principle:

- in group II, the parents of the deceased, first degree relatives, do not remove the brothers and sisters of the deceased, second degree relatives, and their descendants, relatives of grade III or IV, but come together to inheritance, gaining statutory rates according to the law;

- representation of an heir, when someone in succession further in rank, climbs into his ascendents rights to pick the side that would be due to him, if he hadn't been unworthy for the deceased on the date of the opening of the inheritance. Thus, a nephew of the deceased (relative of II ${ }^{\text {nd }}$ degree) will take his part of the legacy, which would have been for his father who died (son of the deceased), even if for the inheritance is called another son of the deceased (a relative of the first degree); descendants from brothers and sisters go up in place and degree of their ascendent to collect part of the legacy that would be their share.

C. The principle of equality between relatives of the same class and degree

According to this principle, if relatives called from a class to inherit are of the same degree, they divide the inheritance in equal shares, if the law does not stipulate otherwise. Thus, if for the inheritance of the deceased two children are coming (both are part of the first class and are relatives of the first degree with the deceased), they divide the inheritance in equal parts, so they will each acquire half of the inheritance.

There are two exceptions of this principle:

- division of the heritage line, when for the inheritance come relatives of same degree as representing. In this situation, the inheritance is divided and each representative (descendent) that came to inheritance in line, that is the part for the ascendant, that it represents.

- dividing lines of inheritance, where brothers and sisters come from different parents when they inherit each other, although of equal degree, brothers and sisters of the deceased both maternal and paternal will take a larger share than brothers and sisters only paternal or maternal, benefiting from a share of the paternal and maternal lines, equality is kept only between brothers and sisters on the same line.

Hereditary succession devolution in Muslim law has many original features, differing in the rules enshrined in our law.

Quran brings together the right of succession to certain heirs who were excluded from the succession until then, the pre-Islamic period is marked by the strong principle of inheritance of male vocation to the exclusion of women from inheritance.

In this context, the Qur'an has given birth to a new possibility of heirs, the heirs of the named parts beside fardh heirs with a natural vocation called aseb.

Along with these categories, the Muslim laws recognize the right of the heirs to the deceased persons related to inheritance contained in the category dhaui al-arham heirs.

The Algerian Family Code establishes in art. 139 the category of heirs:

a) reserved heirs (fardh heirs);

b) universal heirs (aseb); 
c) blood heirs or of the same uterus (dhaui al-arham).

Further, the Algerian Family Code states (art. 140-143) persons belonging to these categories, their rights and the principles of hereditary devolution.

According to the Qur'an, the general principles of hereditary succession in Muslim devolution law are as follows:

A. The principle of priority of class of heirs

B. The principle of the priority of degree of kinship of the same class of heirs

C. The male principle

D. The principle of the connection between relatives of the same class of heirs

These general principles of the transfer on hereditary succession operate on all three categories of heirs announced, joined by specific rules of each category of heirs.

A. The principle of priority of class of heirs

The Muslim law has a very particular vision on the criteria for determining the classes of heirs. Thus, the legislator expressly determines three categories of heirs that includes people from several "classes" of heirs that would correspond to our right. Within each category of heirs fardh, aseb and dhaui al-arham heirs, we distinguish classes grouped by different criteria. The Algerian family code defines who belongs to each category of heirs.

1. Reserved heirs (fardh) according to art.140 of the Code, are those whose share of succession is legally determined by assigning parties. The concept of inheritance "reserved" does not overlap the concept of heirs regulated in our civil law. In Muslim law the notion of "reserved" refers to a part (that is fardh) of heritage that is precise and determined by law, the due share of each heir in this category.

Parties are legally determined in a number six: half, quarter, optima, two thirds, one third and one sixth.

Differences in rank and power to go kinship bond within each class of this category of heirs, exclusions can be total or only partial materializing an order of preference of classes of heirs.

The Algerian family code distinguishes between male heirs and reserved female heirs in art. 141 and 142.

Male reserved heirs are: father, paternal ascendancy - whatever its degree of kinship, husband, brother and uterine brother.

Female reserved heirs are: daughter, descendant of son - whatever their relationship, mother, wife, father and mother ascendant - whatever their relationship, good sister, sister inbred and uterine sister.

2. Universal heirs (aseb). According to Article 150 of the Algerian family code "universal heir (aseb) is entitled to all succession where there is another heir or what remains after the division of the inheritance reserved heirs' parties (fardh)". Aseb heir gets nothing if the division of inheritance succession lies with the reserved heirs.

Of these legal rules it follows that according to the order of preference to the call to the succession, aseb heirs will come to inherit only if the distribution of the parties as to the proper fardh heirs remains something of an inheritance. This statutory provision, however, is more complex than just an expression because the thesis according to which the aseb heirs come to inheritance provided have remained "something" following the sharing of fardh heirs, it refers to classes of heirs that are part of this category, but having a bond of kinship "in force". The provisions of the law are coming just to supplement the provisions of the Quran which puts heirs in the highest ranking in this category, of course, those with a very close kinship ties and male.

According to art. 151 of The Algerian Family Code, the universal heirs (aseb) divide in three classes:

a) universal heir - aseb - through himself

b) universal heir - aseb - through other

c) universal heir - aseb - with other. 


\section{C.T.Popa}

Aseb heirs are relatives on the male side and of the male gender.

This category of heirs has special rules that determines the exact succession for each class of heirs based on a preference order.

3. Heirs by uterus or by blood (dhaui al-arham)

This category includes the rest of the relatives who do not belong to either of the first two categories mentioned, fardh and aseb. Here we encounter the division into four classes of heirs, who will find the specific vocation of the legacy, on pre-announced rules specific to this category of beneficiaries.

$B$. The principle of degree of kinship between same class of heirs

This principle finds its application in each of the categories of heirs. It is a basic principle of the right to inherit as a Muslim and operates similarly to ours. According to this principle, a relative closer to the deceased may exclude from inheritance a relative that is further.

\section{The male principle}

This principle draws its origin since the preislamic period, the right to inheritance being admitted only to male persons, outlining a succession law granted exclusively to men. The Qur'an, however, keeps this principle, gives another sense, the one of benefit from a double part of the legacy, so the called male heir will inherit alongside a female heir of the same class and same degree of kinship and take double of what the woman receives.

For example, if the deceased leaves behind a son and a daughter, the son will take $2 / 3$ of the inheritance and the daugher $1 / 3$. If the husband dies, the woman who is a now a widow will receive $1 / 4$ of the inheritance, but if the other way round, the male widow will receive $1 / 2$ of the inheritance.

$D$. The principle of the bond between relatives of the same class of heirs.

The words "bon connection" defines a situation in which equality of kinship, the link group of collaterals may not be the same. In this case, the good brothers will exclude the brothers from the same father, the descendants of the good brothers will exclude descendants of the brothers of the same brothers decendants.

In conclusion, we may state that as a result of the determination of the categories of heirs called to the inheritance, the application of general principles and special principles governing different categories and classes of heirs will give "winner" heirs in each category, thus allowing the determination of those who are called to the inheritance.

\section{BIBLIOGRAPHY}

1. M. Eliescu, Moștenirea și devoluţiunea ei în dreptul RSR (Inheritance and its devolution as in the RSR right), Academia Publishing House, București, 1966;

2. Carmen Teodora Popa, Drept civil. Succesiuni, (Civil right. Successions) Hamangiu Publishing House, București, 2010;

3. Carmen Teodora Popa, Considerations of surviving spouse inheritance rights under the legal inheritance, publicat în AGORA International Journal of Juridical Sciences, nr.1/2016, http://univagora.ro/jour/index.php/aijjs

4. Ioana Nicolae, Drept civil. Succesiuni. Moștenirea legală, (The Civil right. Successions. Legal inheritance) Hamangiu Publishing House, București, 2014;

5. Dan Chirică, Tratat de drept civil. Succesiunile și liberalitățile, (Treaty on the civil law. Succession and liberties) C.H. Beck Publishing House, București, 2014;

6. Flavius-Antoniu Baias, Eugen Chelaru, Rodica Constantinovici, Ioan Macovei, Noul Cod civil. Comentariu pe articole, (The New Civil Code, Commentaries on articles) Ediția 2, C.H. Beck, Publishing House București, 2014;

7. Ioan Popa, Drept civil. Moșteniri și liberalități, Universul juridic (The Civil law. Inheritance and liberties. Juridical universe) Publishing House, București, 2013; 
8. Daniela Negrilă, Moștenirea în noul Cod civil. Studii teoretice și practice, (Inheritance in the New Civil Code. Theoretical and practical studies) Ediția a II-a, Universul Juridic Publishing House, București, 2015;

9. Franscisc Deak, Romeo Popescu, Tratat de drept succesoral. Moștenirea legală, (Treaty on succession right. The legal inheritance) vol. I, Universul Juridic Publishing House, București, 2013;

10. Maria Marieta Soreață, Noutăți legislative în materia succesiunilor introduse prin noul cod civil, (New regulations in succession matters introduced in the New Civil Code) Hamangiu Publishing House, București, 2013;

11. Bernard Durand, Droit musulman. Droit succesoral, Litec, Libraire de la Cour de cassation, Paris,1991;

12. DARAKE, YASIN. A. I.., Succession in Islamic Sharia, Facultatea de teologie (sharia `a), Universitatea iordaniană, Editura AL-RISALA, Beirut, Liban, ediţia a IIIa, 1986.

13. Coranul ce Sfant (The holy Quran) Traducerea sensurilor şi comentarii, Editia I, 1997, Romania.

14. Law no. 84-11 of June 9th 1984 related to the Algerian family code)

15. Legea succesorală siriană, iordaniană, kuweitiană, marocană- sinteză (sintesis of the Succession law in Syria, Jordan, Kuweit, Maroco)

16. Egyptian succession law no. 77/1943.) 